\title{
INTEGRATING MOBILE LISTENING AND PHYSICAL ACTIVITY TO FACILITATE INTENTIONAL AND INCIDENTAL VOCABULARY ACQUISITION
}

\author{
Tetiana Zubenko \\ Petro Mohyla Black Sea National University, Mykolaiv, Ukraine \\ tetyana.zubenko@chmnu.edu.ua
}

\author{
Allan Shwedel \\ Salem State University, Salem, Massachusetts, U.S.A. \\ ashwedel@salemstate.edu
}

\begin{abstract}
This paper examines the development and effectiveness of a strategy that promotes rapid vocabulary retention among university students who are learning English as a second language. This approach to vocabulary acquisition is based on research that shows that activating implicit memory has a stronger effect than simply activating intentional memory. The hypothesis was that listening to carefully structured mobile English vocabulary lessons during routine physical activity would have a significant and positive effect on students' vocabulary acquisition and performance. The audio lessons were designed to introduce vocabulary by moving from L1 to L2. Participants $(\mathrm{N}=51)$ were first-year Ukrainian university students majoring in English as a second language. Their average age was 17-18. They were randomly assigned to one of three classes, one experimental and two comparison. The experimental group used the "integrating physical activity with listening to vocabulary lessons" strategy in addition to the traditional intentional learning strategy used by the comparison group. The results indicate that performance on the End-of-Unit test benefitted students who were in the Listening While Physically Active group. Their mean score was 81.9 versus 63.2 for the Comparison group. Results from a oneway ANOVA indicate that exam performance difference was statistically significant, $\mathrm{F}=8.761, \mathrm{df}=1, \mathrm{p}<05$. Mobile devices offer students multiple opportunities to listen to, and pronounce, new vocabulary based on L1 to L2 translation while performing routine physical actions. This allows students to create not only receptive but also reproductive skills of L2 translation and communication.
\end{abstract}

Keywords: vocabulary acquisition; mobile listening; physical activity; implicit memory; audio dictionary.

\section{Introduction}

No one doubts the fact that the main key in learning a second language (L2) is vocabulary memorising and the ability to express a person's opinion with its help is what leads to effective communication with other L2 speakers. Possession of a large reserve of words facilitates the expression of a person and promotes understanding of each other. Indeed, words are the building blocks of the language. Teachers of foreign languages understand that the vocabulary is one of the cornerstones of any curriculum. Therefore, higher education institutions allocate a significant amount of time in language courses to the study of lexical material. The creation and use of strategies that promote quick memory and long-term memory retention are very relevant to the vocabulary of L2 (Kornell, 2009).

The primary goal of this study was to examine the effects of integrating mobile vocabulary listening with physical activity on vocabulary acquisition among ESL university students. The main research question was as follows: Does mobile vocabulary listening during physical activity have a significant effect on ESL learners' vocabulary acquisition and usage?

The hypothesis was that mobile English vocabulary listening during physical activity would have a significant and positive effect on students' vocabulary acquisition and performance.

\section{Literature review}

Vocabulary knowledge means that to learn words there needs to be some focus on developing both receptive and productive knowledge, and there also needs to be an emphasis on learning the different aspects of knowledge that make up form, meaning, and use. Different vocabulary learning activities focus attention on different aspects of knowledge. This means that it is likely to take a number of encounters with a word in a number of different activities to fully learn a word (Nation, 2001; Webb, 2013).

\section{Integrating vocabulary acquisition with physical activity}

The connection between the vocabulary acquisition and activity was noticed by researchers long ago. At the same time, the researchers argue that task-essentialness - the relationship of a vocabulary item within an activity as the goal of the task - is also important for lexical learning and retention, along with exposure to words in meaningful contexts. The authors showed good evidence for the support of learning/retention enhancement when a lexical item becomes the focus of goal-directed action, e.g. doing yoga (Morgan, 2011), and through actions (Liu \& Chen, 2014). There have also been attempts to explore accelerated language 
learning during relaxation while listening to music (Lozanov, 1978). Incidental acquisition of meaning through reading was investigated by Webb (2008), Waring and Takaki (2003), through television by Webb and Rodgers (2009), through watching YouTube videos and reading blog posts by Arndt and Woore (2018). Restrepo Ramos, in his analysis of incidental learning of vocabulary in second language acquisition through reading, says that "beginners and advanced learners can benefit from reading and listening activities correspondingly that include multimodal e-learning technologies, even perhaps for the incidental acquisition of multi-word phrases and collocations. If further research focuses on how we can implement effectively Web 2.0 tools in tasks that improve retention and recall of basic and complex lexical items at the meaning and form level, we can build on our current literature and gain a deeper insight into the acquisition of L2 vocabulary in the 21 st century" (Restrepo Ramos, 2015, p. 165).

\section{The Use of mother tongue in teaching English}

The Ukrainian group of methodologists distinguishes translational and nontranslational methods of the semantics of lexical units (Nikolaieva, 2002). Let's consider the translational method which is a traditional method of learning vocabulary the essence of which is in memorising L2 words along with their translation or synonyms (Webb, 2009). Other researchers regard this method as quite effective because it allows to study a large number of words in a short period of time. For example, Thorndike (cited by Webb, 2009) found that students can learn from 9 to 58 L2 word pairs per hour with an average of 34 units; Webb (2009) found that students can memorise up to 166 L2 word pairs in an hour; Nation (20001) demonstrated that students can learn from 30 to 100 L2-L1 word pairs with translation without much effort. However, researchers do not specify whether intentional or incidental learning leads to retaining so many lexemes. The number of learned words depends on their characteristics: form, meaning, similarities with the words of the native language in terms of sound or spelling, compatibility, ability to form derived words, frequencies of use in speech, and so on. However, to learn new words in an hour does not mean to remember them all one's life.

Therefore, retaining lexical units in memory is directly related to preventing forgetting. And it is one of the main problems in mastering L2 vocabulary. Unfortunately, this problem has not been studied enough. According to psychologists' research, about $60 \%$ of learned information is forgotten in the first 12 hours after memorisation, then the forgetting process goes at a much slower pace so that after 6 days approximately only $20 \%$ of the original information is remembered (Skrypchenko, Dolynska \& Ohorodniichuk, 2005). Therefore, for better retention, it is recommended to use repetitions in several instances of spaced practice. It is known that the number of repetitions of words (from 15 to 20) for their retention in memory, followed by the use in receptive speech after a three-month period depends on the nature of the word and should be distributed as follows: seven repetitions within the first week; four repetitions in the second week, three in the third, two in the fourth week, and the rest - at any interval in time (Nikolaieva, 2002).

As it is known, the process of teaching and learning vocabulary runs in phases. There are various classifications of the phases of mastering lexical units. We adhere to the opinion of Potiuk (2014) who distinguishes three phases in mastering professional vocabulary in the formation of English Lexical Competence (ELC):

I. Operational-automatic: in this phase, lexical units are first introduced along with their semantic components which include the prevailing receptive assimilation of lexical material, that is, perception of the sound and graphic form of the word.

II. Reproductive-activity: the phase of improvement and automation of students' actions with new linguistic units (further training of lexical items in order to improve professionally oriented lexical knowledge and skills).

III. Communicative-strategic: the phase of development and further automation of the students' actions with vocabulary in speech and control the level of formation of ELC. (Potiuk, 2014, p. 3)

A survey of first-year students in a Ukrainian university conducted by the first author, showed that when students are first acquiring new words in activities outside the classroom they listen to new L2 vocabulary with the subsequent translation it into L1 without pronouncing aloud the words they were listening to, that is during this process only receptive skills and the skills of recognising L2 lexical units and translating them into the mother tongue are formed. We believe that such an approach does not contribute to effective vocabulary retention, nor to the formation of L2 reproductive and communicative skills. We adhere to the opinion that to learn to communicate, it is necessary to develop productive skills that are formed on the basis of both reproductive and productive skills. This in turn suggests: "the choice of the lexical unit, the combination and implementation of the lexical unit in oral and written speech, the pronunciation skills, that is, articulation and intonation, skills of graphic representation of speech and writing according to the spelling rules" (Nikolaieva, 2002, p. 62). That is, before creating a statement in L2, it is necessary to create an 
opinion which in the first phase of mastering new words is usually formed in the mother tongue. The student should select in his/her memory the necessary lexical units from the corresponding thematic lexical field, combine them in a grammatically correct phrase, choose the correct articulation and intonation (if speech is oral) or corresponding graphic representation (if speech is in written form). This means that the process of formation of reproductive and communicative skills takes place in the direction from L1 to L2. L2 learners always use their native language because they always think most often in their L1, even at the advanced level (Mahmoud 2006).

Taking into account the above studies and our observations, in the receptive and reproductive phases of semantics and training of lexical units, we propose to listen to audio recordings of L1-L2 word pairs and their combinations on specific topics during physical activities beyond the classroom (travelling, walking in the park, on the way to work or to the university, etc.) followed by pronouncing them aloud. In such a way, both receptive and reproductive skills of L2 translation and communication are formed. This type of audio recording can be called "A Thematic Bilingual Audio Dictionary". With multiple instances of listening to L1-L2 lexical units and their phrases with their subsequent pronunciation, the process of combining two sound forms of the same image or concept occurs in a human brain. Moreover, in the process of simultaneous listening, pronouncing and physical activity, incidental memory is activated, which is much stronger (Skrypchenko, Dolynska \& Ohorodniichuk, 2005). This process boosts subconscious acquisition of lexical items. Such a mechanism of retention contributes to the study of a sufficiently large number of lexical units in a short period of time, creating a lexical field in a person's memory on a specific theme.

Using modern devices (mobile phones, smartphones, mp3 players, etc.) allows students to listen to the thematic bilingual dictionary anywhere and at any time. For the purpose of preserving lexical items in memory and preventing them from forgetting, the thematic audio dictionary can be listened to at regular intervals throughout a lifetime, depending on the needs and individual qualities of memory of each person. After, at least the initial use of the thematic audio dictionary, further practice using these lexical items in written or mobile applications will contribute to better retention and the development of receptive, reproductive and productive skills of translation and communication. The use of L1 in the creation of a thematic bilingual audio dictionary is predicated by the fact that a person who studies L2 always uses their mother tongue in the process of creating their own thoughts. The native language is a resource that people use both consciously and subconsciously in the process of organising L2 communication. We recommended to our students that they pronounce the words and phrases aloud. Just aloud, and not in the mind or whisper, since in this case, besides the auditory memory, such types of memory as verbal-logical, articulatory, muscular are also activated, which, in turn, also have a positive impact on the processes of vocabulary acquisition and retention.

\section{The use of mobile phones in teaching and learning languages}

It is difficult to overestimate the role of mobile devices in modern life. Mobile devices are often ubiquitous as well as always connected, they are ideal for learning in a variety of ways to fit a particular time and place (Malamed, 2012). Some American researches indicate benefits of using mobile devices as educational tools, including increased student engagement and motivation, knowledge creation, collaborative learning, global awareness, effective cost and time management (Lahiri, \& Moseley, 2012). When it comes to language learning mobile devices have become the demand of the day as they have changed the way people learn languages.

\section{Development of the Audio Ukrainian - English Dictionary}

Units were developed for vocabulary to be studied by both first- and second-year students in the following sequence: a new word and its phrases were pronounced in the students' mother tongue and after a short pause their meaning in L2. The use of L1 is caused by the fact that at the phase of learning a foreign language, any person thinks in her/his native language, translates her/his thoughts in mind into a foreign language and only then reproduces them aloud. In order to form the skills of transforming thoughts from the mother tongue into L2, such training of learning the vocabulary in the mode of L1-L2 with their repeated listening and pronouncing aloud are necessary.

For this research study, first year students were covering vocabulary related to homes and apartments. This is the fifth unit covered during the academic year. For this unit "Home Sweet Home" 7 audio lessons were created by the first researcher. These vocabulary lessons covered topics such as "materials", "opinions about housing arrangements", etc. Each audio vocabulary lesson was about 2 to 8 minutes long. Lessons were kept short so that students could potentially listen and repeat an audio lesson multiple times on their 
walk to the dormitory or commute home. Students could access the lessons via the Telegram app on their mobile phone (See Figure 1).

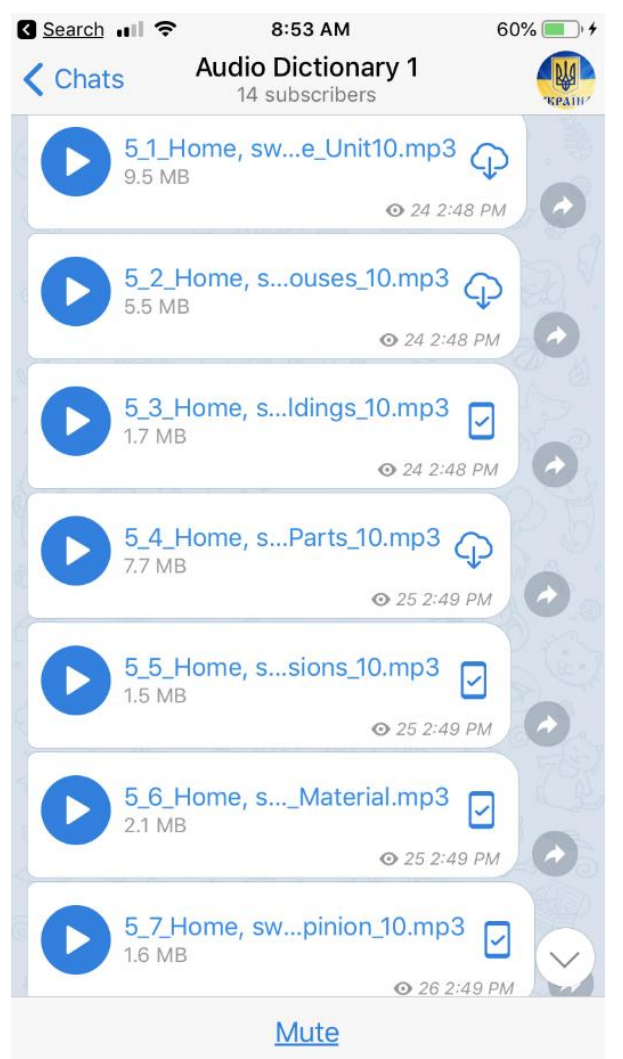

Figure 1. The screenshot of "A Thematic Bilingual Audio Dictionary" for first year students on the Telegram application

It was recommended to students that the number of repetitions of each audio vocabulary lesson (from 15 to 20 or more) should be distributed as follows: seven repetitions within the first week; four repetitions in the second week, three in the third, two in the fourth week, and the rest - at any interval in time. The general sequence of each lesson is presented in Table 1 and the flow of vocabulary instruction is shown in Figure 2.

\section{Table 1}

Incidental and intentional vocabulary acquisition in the experimental and comparison groups

\begin{tabular}{|c|c|}
\hline \multicolumn{2}{|c|}{ Introduction and Training of Vocabulary in the Experimental Groups } \\
\hline & $\begin{array}{c}\text { Traditional way vocabulary is introduced first in the classroom } \\
\text { 1) vocabulary is introduced in L2 with definitions in L2 }\end{array}$ \\
2) or with translations in Ukrainian (L1) \\
3) or by showing pictures that represent the vocabulary words \\
4) sentence example, "fill in" exercises, etc.
\end{tabular}




\begin{tabular}{|c|c|}
\hline 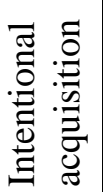 & $\begin{array}{l}\text { Training Vocabulary in the Exercises at Home } \\
\text { Step \#1 - Complete oral and written exercises based on the vocabulary list } \\
\text { (L1\&L2) } \\
\text { Step \#2 } \text { - Practice writing the words to remember them (L2) }\end{array}$ \\
\hline \multicolumn{2}{|r|}{ Introduction and Training of Vocabulary in the Comparison Groups } \\
\hline 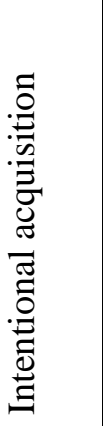 & $\begin{array}{l}\text { Traditional Way Vocabulary is Introduced First in the Classroom } \\
\text { 1) vocabulary is introduced in L2 with definitions in L2 } \\
\text { 2) or with translations in Ukrainian (L1) } \\
\text { 3) or by showing pictures that represent the vocabulary words } \\
\text { 4) sentence example, "fill in" exercises, etc. } \\
\text { Training Vocabulary in the Exercises at Home } \\
\text { Step \#1 - Complete oral and written exercises based on the vocabulary list } \\
\text { (L1\&L2) } \\
\text { Step \#2 - Practice writing the words to remember them (L2) }\end{array}$ \\
\hline
\end{tabular}
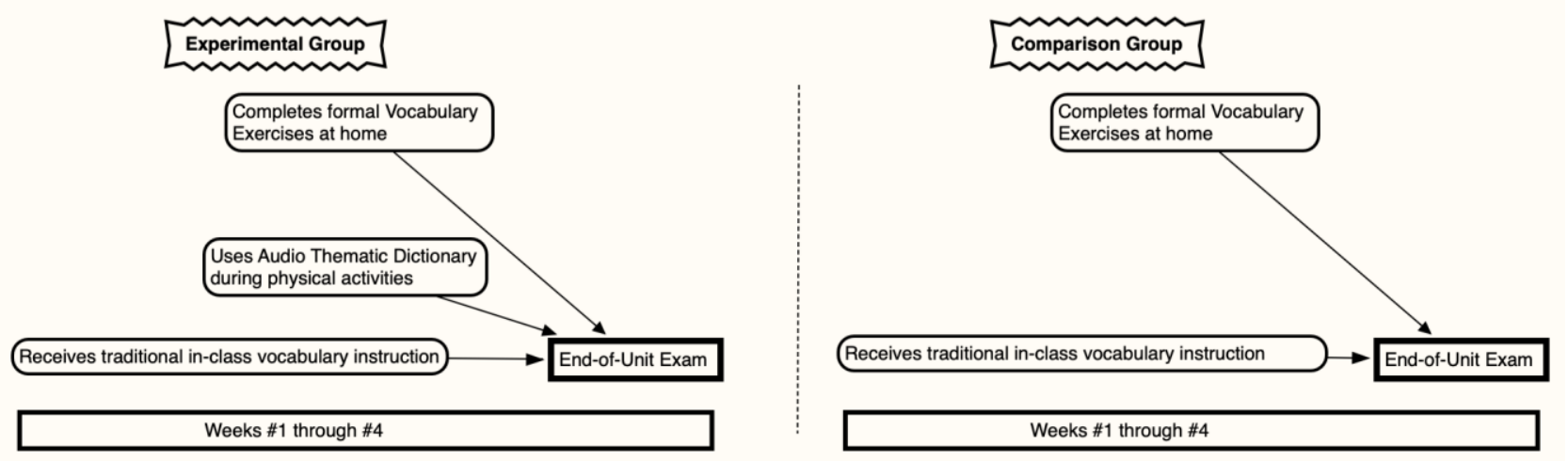

Figure 2. The flow of vocabulary instruction.

\section{Methods}

The researchers used an experimental design in this study. Participants $(N=51)$ were first-year students who were randomly assigned to three classes, one experimental and two comparison. The difference between the treatment groups was that the experimental group used the "integrating physical activity with listening to vocabulary lessons" strategy in addition to the traditional intentional learning strategy. The rationale for this is because prior research has revealed that integrating second language acquisition with different activities is more useful (Morgan, 2011; Kerka, 2000) When performing the experimental task, for the most part, students used the time allotted on the way to the university, walking in the park, etc. The experimental task did not require the students to allocate any of their spare time specifically to this activity since it was to be part of their daily routine. The use of mobile phones allows them to perform listening an unlimited number of times anywhere without causing fatigue or boredom.

1. Integrating-listening strategy group: to learn during one month 120 new topical words students in the integrating-listening groups were instructed with an integrating vocabulary listening strategy and asked in addition to home assignment exercises to listen to every audio vocabulary lesson they had on the Telegram app on their mobile phones (See Figure 1) 7, 4, 3, 2 times - 4 repeating cycles during their physical activity beyond the classroom (e.g., while walking in the park, training in the gym, on the way to the university, etc.) using their mobile phones and pronounce them aloud. Since the 7 audio vocabulary lessons were organised in the sequence that the new vocabulary was being covered in class, students were expected to listen to the audio vocabulary lessons in the proscribed sequence (See Table 1, Figure 2). Periodically, students were reminded to go back to the first lessons and listen to them in the proscribed sequence regularly.

2. Traditional strategy group: to learn 120 new topical words students used traditional intentional way of learning vocabulary beyond the classroom (e.g., intentional memorising, defining the meaning of the words, sentence example, "fill in" exercises, etc.) 


\section{Participants}

Three groups of the first-year university students of philology department who study English as a second language were invited to join the study. In future, they will work as philologists, teachers, translators, interpreters, etc. The average age of participants was 17-18 years. They had been learning English for 11 years at school. Their English proficiency level was A-2 according to the descriptions of CEFR standard and their scores on entrance independent testing. The average English proficiency of each group was assumed to be equal.

\section{Results}

Hypothesis \#1: Students who listen to vocabulary lessons while physically active (LWPA) will perform better on End-of-Unit exams than students who do not use audio vocabulary lessons.

The End-of-Unit results are presented in Table 2. Students in the LWPA group had a mean score of 81.9 versus 63.2 for the Comparison group. Results from a one-way ANOVA indicate that exam performance difference was statistically significant, $\mathrm{F}=8.761, \mathrm{df}=1, \mathrm{p}<05$ (See Table 3).

As can be seen in Table 2, the LWPA group students outperformed Comparison group students in each of the sub-sections of the End-of-Unit exam. Since it was hypothesised that oral comprehension would be most affected by this active listening to audio vocabulary lessons (see Hypothesis \#2), a post-hoc analysis of End-of-Unit results was done to control for the potential influence of oral comprehension performance. Thus, the oral comprehension scores were subtracted from each student's total score. Results from the Tukey/Kramer HSD test indicate that the LWPA group outperformed the Comparison group on literacy components of the End-of-Unit Exam, Q-stat $=3.01, \mathrm{df}=49, \mathrm{p}<.05$. (See Table 2.)

Table 2

End-of-Unit Exam - Mean Percentage Scores and Tukey/Kramer Post-Hoc Tests

\begin{tabular}{|c|c|c|c|c|c|c|c|c|c|c|}
\hline \multirow[b]{2}{*}{ Exam Component } & \multirow{2}{*}{$\begin{array}{c}\text { Max. } \\
\text { \# of } \\
\text { Points }\end{array}$} & \multicolumn{3}{|c|}{ LWPA } & \multicolumn{3}{|c|}{ Comparison } & \multicolumn{3}{|c|}{ Tukey/Kramer HSD } \\
\hline & & $\mathbf{M}$ & SD & $\mathbf{n}$ & $\mathbf{M}$ & SD & $\mathbf{n}$ & df & q stat & $\mathbf{p}$ \\
\hline Overall Total Score & 100 & 81.1 & 19.8 & 14 & 63.2 & 18.1 & 37 & -- & -- & -- \\
\hline $\begin{array}{l}\text { Total Score Minus Oral } \\
\text { Comprehension Scores }\end{array}$ & 70 & 58.3 & 10.3 & 14 & 49.5 & 14.0 & 37 & 49 & 3.01 & $0.038^{*}$ \\
\hline $\begin{array}{l}\text { Ia. Oral Comprehension: } \\
\text { Identify Speaker }\end{array}$ & 7 & $91.8 \%$ & $2.7 \%$ & 14 & $74.5 \%$ & $5.1 \%$ & 37 & 49 & 3.68 & $0.012^{*}$ \\
\hline $\begin{array}{l}\text { Ib. Oral Comprehension: } \\
\text { Answer Questions }\end{array}$ & 23 & $71.4 \%$ & $\begin{array}{c}11.9 \\
\%\end{array}$ & 14 & $36.5 \%$ & $8.9 \%$ & 37 & 49 & 5.06 & $0.001 *$ \\
\hline II. Translate from English & 10 & $90.7 \%$ & $3.5 \%$ & 14 & $83.1 \%$ & $3.2 \%$ & 37 & 49 & 1.90 & 0.190 \\
\hline III. Translate from Ukrainian & 10 & $90.0 \%$ & $1.2 \%$ & 14 & $64.6 \%$ & $5.6 \%$ & 37 & 49 & 5.41 & $0.000 *$ \\
\hline $\begin{array}{l}\text { IV. Define English } \\
\text { Words/Phrases }\end{array}$ & 10 & $83.6 \%$ & $4.6 \%$ & 14 & $66.9 \%$ & $10.1 \%$ & 37 & 49 & 2.56 & 0.076 \\
\hline $\begin{array}{l}\text { Va. Sentence Completion: } \\
\text { English }\end{array}$ & 5 & $90.0 \%$ & $2.3 \%$ & 14 & $81.1 \%$ & $9.1 \%$ & 37 & 49 & 1.49 & 0.298 \\
\hline $\begin{array}{l}\text { Vb. Recognize Paragraph } \\
\text { Topic }\end{array}$ & 5 & $88.6 \%$ & $2.9 \%$ & 14 & $83.3 \%$ & $7.1 \%$ & 37 & 49 & 0.88 & 0.535 \\
\hline $\begin{array}{l}\text { VI. Use New Vocabulary } \\
\text { In a Sentence }\end{array}$ & 30 & $76.2 \%$ & $4.6 \%$ & 14 & $66.1 \%$ & $5.4 \%$ & 37 & 49 & 1.99 & 0.165 \\
\hline
\end{tabular}

* Indicates an alpha $<.05$

Hypothesis \#2: The positive impact of listening to vocabulary lessons while physically active (LWPA) will be most evident in the area of Oral Comprehension.

A mixed-factors repeated measures ANOVA was done to determine if there was an interaction between the LWPA/Comparison group effect and scores across the different test components. To do these analyses, the sub-section scores were converted to percentage correct so that meaningful comparisons could be made among the 8 sections. The results in Table 4 show that indeed there is a significant interaction effect. A series of post hoc Tukey HSD tests were done compare performance between the groups on each sub-domain. As predicted in Hypothesis \#2, significant differences favouring the LWPA group were observed in the two Oral Comprehension sub-sections. 
Table 3

End-of-Unit Exam Total Score Percentage by Treatment ANOVA

\begin{tabular}{|l|c|c|c|c|c|c|}
\hline & SS & df & MS & F & p & Omega Sq. \\
\hline Between Groups & 0.328 & 1 & 0.328 & 8.761 & 0.005 & 0.132 \\
\hline Within Groups & 1.837 & 49 & 0.037 & & & \\
\hline Total & 2.165 & 50 & 0.043 & & & \\
\hline
\end{tabular}

Hypothesis \#3: Given the tendency among L2 learners to use L1 to form responses in mind and express their opinion in L2, students utilising audio lessons that train new vocabulary through L1 would be more likely to acquire, retain and translate accurately from L1 to L2 than students who train new vocabulary and translate from L2 to L1.

Post-hoc analyses of the Translating from Ukrainian to English subsection indicated that there was a significant positive effect for the LWPA group. This significant effect supports H3. See Table 2 for the Tukey/Kramer results for each sub-section.

Table 4

Treatment by Exam Sub-Section Percentage Score Repeated Measures ANOVA

\begin{tabular}{|l|l|l|l|l|l|}
\hline & \multicolumn{1}{|c|}{ SS } & \multicolumn{1}{c|}{ df } & \multicolumn{1}{c|}{ MS } & \multicolumn{1}{c|}{ F } & p \\
\hline Between Subjects & 14.619 & 50 & & & \\
\hline - Treatment & 2.005 & 1 & 2.005 & 7.788 & 0.007 \\
\hline - Error & 12.614 & 49 & 0.257 & & \\
\hline Within Subjects & 18.136 & 357 & & & \\
\hline - Exam Sub-Sections & 6.032 & 7 & 0.862 & 26.006 & 0.000 \\
\hline - Interaction & 0.740 & 7 & 0.106 & 3.188 & 0.003 \\
\hline - Error & 11.365 & 343 & 0.033 & & \\
\hline Total & 32.755 & 407 & 0.080 & & \\
\hline
\end{tabular}

Hypothesis \#4: The amount of time spent listening while physically active will be reflected in performance on the End-of-Unit exam with increases in listening time being matched by increases in exam scores.

Table 5 shows that while there is a small positive correlation, the results do not show a statistically significant effect related to the amount of listening time, $\mathrm{r}=.346, \mathrm{P}>.05$. The standard deviation and range data show that there was a wide variability in both the frequency of listening and the average amount of listening time among the students in the Audio Vocabulary group. Thus, the non-significant results among this small sample are not surprising.

Table 5

Frequency and Average Time Listening to the Vocabulary Lessons While Active

\begin{tabular}{|l|r|r|r|r|}
\hline & Mean & SD & $\mathbf{N}$ & Range \\
\hline Average \# of Times Listening & 19.8 & 15.2 & 14 & $7-64$ \\
\hline Average Time Spent Listening & $5.9 \mathrm{hrs}$. & 5.0 & 14 & $1.2 . \mathrm{hrs} .-19.8 \mathrm{hrs}$. \\
\hline
\end{tabular}

\section{Discussion}

The results indicate that the performance on the End-of-Unit test favoured students who were in the Listening While Physically Active (LWPA) group with the differences in total score being statistically significant even when the oral comprehension portion of the exam was removed. This finding supports the hypothesis that students' initial acquisition of vocabulary can be enhanced through incidental listening while physically active. Furthermore, the finding that LWPA students' ability to translate vocabulary from Ukrainian into English was better than the Comparison group's performance suggests that training L2 vocabulary by going from L1 to L2 is an effective pedagogical strategy. Future research should examine this approach within the traditional classroom setting. The importance of L1 in mastering the L2 skills is discussed widely (Kavaliauskienè, 2010; Mattioli, 2004; Mahmood, 2006; Ross, 2000; Yadav 2014). In the use of L1, we consider translation as one of the effective ways of L2 vocabulary acquisition. Nation (2001, 
p. 351) regards translation as an effective way to measure the learners' receptive as well as productive knowledge of vocabulary. Translation is sometimes referred to as the fifth language skill alongside the other four basic skills (listening, speaking, reading, writing) “... since it promotes communication and understanding between strangers" (Ross, 2000). Recently there has been a revival of interest in translation due to the shift of its emphasis - to using a mother tongue as a resource for the promotion of language learning. Therefore, translation can serve as a tool for learning vocabulary too.

Finally, for the LWPA group, while there was not statistically a significant effect on test score related to the amount of time that students spent listening to the vocabulary lessons, even for this small sample the correlation suggested a moderate relationship. This potential relationship should be investigated with larger samples and across a wider range of new vocabulary.

Given the wide variability in the frequency and amount of time that the LWPA students listened to the Audio Thematic Vocabulary Lessons, future studies should provide more explicit guidance or requirements about the use of this mobile phone resource while studying a new language. For example, the evidence is quite clear in L1 studies of memory that massed-spaced practice is an effective approach to learning vocabulary (Sobel, Cepeda, \& Kapler, 2011). So perhaps there is some minimal frequency and amount of time that students should listen to each mini-lesson. This should be examined systematically.

\section{Conclusion}

Thanks to the developed strategy of using listening in teaching L2 vocabulary at the operationalautomatic phase of presenting and semantics of lexical units in the student's memory in a short period of time students can create a lexical field of about 120 lexemes on a specific topic. Multiple instances of listening to the vocabulary with L1 - L2 translation and the subsequent pronunciation of it while performing physical actions allows students to create not only receptive, but also reproductive skills of L2 translation and communication. This way of vocabulary acquisition activates implicit memory. However, researchers believe that it is advisable to combine two and more ways of learning lexical items, because merely knowing the meanings of words does not necessarily lead to the ability to use them in speech. Therefore, an important factor is the implementation of training exercises on the use of the learned vocabulary in speech as well as in reading. The use of mobile applications is the tool that allows students to perform training exercises multiple times without causing fatigue or boredom. Therefore, the next task we consider is the creation of copyright applications for smartphones with training grammar and conversation exercises and with lexical content, which is proposed for listening in the thematic audio dictionaries.

\section{References:}

Arndt, H. L., \& Woore, R. (2018). Vocabulary learning from watching YouTube videos and reading blog posts. Language Learning \& Technology, 22(1), 124-142. https://doi.org/10125/44660

Kavaliauskienè, G., Mažeikienè, V., \& Valūnaitè-Oleškevičienė, G. (2010). Role of native language in learning English. Santalka, 18(2), 35-42. https://doi.org/10.3846/coactivity.2010.12

Kerka, S. (2000). Incidental Learning: Trends and Issues. Alert No. 18. Washington, DC: ERIC Clearinghouse on Languages and Linguistics. ERIC Digest ED446234.

Kornell, N. (2009) Optimising Learning Using Flashcards: Spacing Is More Effective Than Cramming. Appl. Cognit. Psychol, 23, 1297-1317. https://doi.org/10.1002/acp.1537

Lahiri, M. \& Moseley, J. L. (2012). Is Mobile Learning the future of the 21st Century Education? Educational Considerations from Various Perspectives. Educational Technology, 52(4), 3-13. Retrieved 15 February 2019 from https://www.jstor.org/stable/44430053

Laufer, B., \& Hulstijn, J. (2001). Incidental vocabulary acquisition in second language: The effect of task-enduced involvement. Applied Linguistics, 22(1), 1-26.

Liu, P. L., \& Chen, C. J. (2014). Learning English phrase through actions: A study of mobile-assisted language learning. Interactive Learning Environments, 23(2), 158-171. https://doi.org/10.1080/10494820.2014.959976

Lozanov, G. 1978. Suggestology and the Outlines of Suggestopedia. New York; Gordon Breach, 59.

Mahmoud, A. 2006. Translation and Foreign Language Reading Comprehension: A Neglected Didactic Procedure". English Teaching Forum, 44(4), 28-33. Retrieved 16 February 2019 from https://americanenglish.state.gov/files/ae/resource_files/0644-4-e.pdf

Malamed, C. (2012) What's different about mobile learning? Retrieved 15 February 2019 from The Learning Circuits Blog http://learningcircuits.blogspot.com/2012/02/whats-different-about-mobile-learning.html

Mattioli, G. (2004). "On Native Language Intrusions and Making Do with Words: Linguistically Homogeneous Classrooms and Native Language Use". English Teaching Forum, 42(4), 20-25. Retrieved 16 February 2019 from https://americanenglish.state.gov/files/ae/resource_files/04-42-4-h.pdf

Morgan, L. (2011). Harmonious learning: yoga in the English language classroom. English Teaching Forum, 4, 2-13. Retrieved 16 February 2019 from https://americanenglish.state.gov/files/ae/resource_files/49_4_2_morgan_0.pdf

Nation, I. S. P. (2001). Learning vocabulary in another language. Cambridge, UK: Cambridge University Press.

Restrepo Ramos, F. D. (2015). Incidental vocabulary learning in second language acquisition: A literature review. PROFILE Issues in Teachers' Professional Development, 17(1), 157-166. http://dx.doi.org/10.15446/profile.v17n1.43957 
Ross, N. J. (2000). Interference and Intervention: Using Translation in the EFL Classroom. Modern English Teacher, 9(3), 61-66. Retrieved 16 February 2019 from http://web.tiscali.it/njross/interfereart.htm

Sobel, H. S., Cepeda, N.J., \& Kapler, I. V. (2011). Spacing Effects in Real-World Classroom Vocabulary Learning, Applied Cognitive Psychology, 25, 763-767. https://doi.org/10.1002/acp.1747

Webb, S. (2007). The effects of repetition on vocabulary knowledge. Applied Linguistics, 28(1), 46-65. https://doi.org/10.1093/applin/aml048

Webb, S. (2009). The Effects of Receptive and Productive Learning of Word Pairs on Vocabulary Knowledge. RELC Journal, 40, 360-376. https://doi.org/10.1177/0033688209343854

Webb, S. \& Rodgers, M. P. H. (2009). 'The Vocabulary Demands of Television Programs', Language Learning, 59, 2, 335-366. https://doi.org/10.1111/j.1467-9922.2009.00509.x

Webb, S. (2013). Learning vocabulary in activities. In H. Puji Widodo \& A. Cirocki (Eds.), Innovation and Creativity in ELT Methodology (pp. 121-133). New York: Nova.

Yadav, M.K. (2014). Role of mother tongue in second language learning. International Journal of Research (IJR), 1(11), $572-582$. Retrieved 13 March 2019 from http://citeseerx.ist.psu.edu/viewdoc/download?doi=10.1.1.892.7707\&rep=rep1\&type=pdf

Nikolaieva, S.Yu. (Ed), (2002). Metodyka vykladannia inozemnykh mov u serednikh navchalnykh zakladakh [Methods of teaching foreign languages in secondary schools]. Kyiv, Ukraine: Lenvit.

Potiuk, I.Y. (2014). Formuvannia anhlomovnoi leksychnoi kompetentsii u maibutnikh fakhivtsiv sfery turyzmu na zasadakh navchalnykh stratehii [Formation of English lexical competence for future specialists in the sphere of tourism on the basis of educational strategies] . Naukovi zapysky Ternopilskoho natsionalnoho pedahohichnoho universytety imeni Volodymyra Hnatiuka. Seriia : Pedahohika, 3, 111-116. Retrieved 13 March 2019 from http://nbuv.gov.ua/UJRN/NZTNPU_ped_2014_3_20

Skrypchenko, O., Dolynska L. \& Ohorodniichuk, Z. (2005). Zahalna psykholohiia [General psychology]. Kyiv, Ukraine: Lybid. 